\title{
Optimization of Regional Revenue Through Tourism Sector for Improving Own Source Revenue of Yogyakarta City
}

\author{
Rini Raharti \\ Economics Department \\ Janabadra University \\ Yogyakarta, Indonesia \\ riniraharti@janabadra.ac.id
}

\author{
Fathonah Eka Susanti \\ Management Department \\ Janabadra University \\ Yogyakarta, Indonesia \\ fathonaheka@gmail.com
}

\author{
Titi Laras \\ Management Departement \\ Janabadra University \\ Yogyakarta, Indonesia \\ titilaras@janabadra.ac.id
}

\begin{abstract}
Regional government makes some efforts to improve its economy including in improving Own Source Revenue. One of the efforts for improving Own Source Revenue is by optimizing its potency in tourism sector. The connection between tourism industry and regional revenue is through domestic income and profit sharing tax/non tax. Successful development of tourism sector means that it will increase its role in regional revenue, in which tourism is the main component by considering the influencial factors, such as the number of tourists visiting either domestic or international tourists, the hotel occupancy rate, hotel tax, restaurant tax, entertainment tax and tourism levy. The analysis methodology used in this research was multiple linear regression with domestic income of tourism sector as dependent variable and four independent variables, they were the number of tourists, the hotel occupancy rate, restaurant tax, and entertainment tax. The analysis results obtained show that variables of the number of tourists, the hotel occupancy rate, restaurant tax and entertainment tax have significant influence towards variable of regional revenue of tourism sector. The value of determination coefficient $\left(R^{2}\right)$ is $87,9 \%$ which means that the variety of independent variables in model of regional revenue of tourism sector could be explained by variety of independent variables, namely the number of tourists, the hotel occupancy rate, the restaurant tax and the entertainment tax, whereas the rests, as much as $12,1 \%$, could be explained by other factors outside the model.
\end{abstract}

Keywords: own source revenue, tourism sector, restaurant tax, entertainment tax

\section{INTRODUCTION}

Regional autonomy has authority to organize and manage interests of the local community according to their own initiative based on community's aspirations in line with the law regulations. With the issued of Constitution No.32 Year of 2004 , it states that a region is given right to gain financial sources, among of them are certainty of availability of funding of government in line with government affairs which are submitted, for those aims, regional government must have capacity to dig potencies of Own Source Revenue and Government must transfer them as the income and or share the part of tax income with the Regional Government. And Constitution No. 33 Year of 2004 about the balance of central and regional finance gives big opportunities for region to manage their own natural resources in order to get the optimal results [1]. Each regional government tries hard to enhance their regional economy including in improving their Own
Source Revenue. Besides managing the existed sources of Own Source Revenue, it needs to be improved and also region must always be creative and innovative in searching and developing their potencies of Own Source Revenue so that by getting more Own Source Revenue that are owned, the region will get more income sources which are going to be used in developing their region. One of the efforts to increase Own Source Revenue is by optimizing the potency of tourism sector [2].

According to [3] that tourism sector is increasingly perceived as economy engine of foreign exchange earner for development. Whereas, tourism is service industry which has complex regulatory mechanism because it covers tourist movements from region or country of origin towards tourist destination, then go back to their country of origin which involve various components such as travel agent, guide, tour operator, accomodation, restaurant, artshop, money changer, transportation and others. Tourism also offers various kinds of products and travel diverse, start from natural travel, cultural travel, historical travel, artificial travel, until various special interest travel. According to [4] tourism is one of new industries which is able to produce economic growth fast in provision of employment, standard of living as well as stimulating other productivitiy sectors. Furthermore, according to [4] as the complex sectors, they also include real classical industries such as handicraft industries and souvenirs.

Successful development of tourism sector means that it is going to improve its role in regional revenue, in which tourism is the main component with regard to the factors influnced, such as the number of tourism attractions offered, the number of tourists visiting either domestic or international tourists, the hotel occupancy rate, income per capita, big or small hotel and restaurant tax, and big or small tourism attraction levy [5]. Yogyakarta is one of tourist destination cities from local or foreign country. If the tourists are interested in spending their time in Yogyakarta, it will get positive effect to develop tourism business. Therefore, tourism industry is one of service sector that is very important to be developed.

Government Tourism office of Yogyakarta city in 2019 noted the visiting number of domestic and foreign tourists in Yogyakarta indicated an increase from year to year. In 2016 there were 3.5 millions, in 2017 , there were 3.8 millions and in 2018, the number was 4,1 millions. The quantity was dominated by domestic tourists. Based on the Plan of Strategy (Rencana Strategis (Renstra)) 2017-2022, the target of tourists in Yogyakarta city is as many as 3.7 millions. It is estimated 
that there is increasing number as much as $5-10 \%$ than the visiting rate in 2018. Therefore, the researcher is interested in conducting research about regional revenue of tourism sector in Yogyakarta city in order to increase Own Source Revenue [6]. Tourism sector is one of sectors which gets main priority in order to improve regional economic structure as well as to be able to increase independence and competitiveness, therefore, hopefully it is able to give big enough contribution towards Own Source Revenue [7]

One of the indicators used to know the impact of tourism towards regional economy and also as one of the determinant factors the high level of regional economy are by Own Source Revenue accepted of that region, The Own Source Revenue are sourced on regional tax, regional retribution profit of regional company, service income and legitimate Own Source Revenue. The city of Yogyakarta has big potency to be developed. It can be seen from more and more the number of public places in Yogyakarta until 2019 and various kinds of tourism attraction, historical building and many more. However, the high potency has not been optimized to improve Own Source Revenue. So that, it needs to conduct research about regional income from tourism sector and what factors which influence of regional income of tourism sector are, so that it can get answers of those problems. As for, the questions discussed in this research are (i) what are factors which influence regional income from tourism sector in Yogyakarta city (ii) How much influence are those factors towards regional income from tourism sector in Yogyakarta city. Whereas the objectives of the research are (i) analizing the factors which influencing regional income of tourism sector in Yogyakarta city, (ii) analizing the factor which is the most influencing towards regional income of tourism sector in Yogyakarta city.

\section{LITERATURE REVIEW}

\section{A. Tourism}

Tourism is an activity of doing travel with the aim is to get enjoyment, look for satisfaction, know something, improve healthy, enjoy exercises or take a rest, do assigment, have pilgrimage and others. It is not a new activity done by people today [8]. Based on wide definition, tourism is a temporary travelling from one place to other places which is done by an individual person or group as a way to find out balance or harmony and happiness with living environment in dimension of social, culture, natural and knowledge [9]. Someone can go travelling by various way due to different reasons as well. Travelling is considered as tour if it meets three conditions needed, namely:

- Must be temporary.

- Must be voluntary in the sense that there is no coercion.

- Not working which bring about wage or payment.

\section{B. Own Source Revenue}

Based on Constitution No.33 year of 2004, Own Source Revenue is an acceptance which is obtained by the region from sources inside its own region that are taken based on regional regulation which is in line with constitution applied [10]. Own Source Revenue is a source of Own Source
Revenue digged in the region which is used as authorized capital of regional government in funding their development and businesses of region in order to minimize fund dependancy from central government [11].

\section{The Number of Tourism Attractions}

Tourism attractions in Yogyakarta involve various kinds of tourism places, such as not only natural tourism, recreational park, but also art and culture in Yogyakarta, they become their own charm for tourists who are being visited. According to [12] tourism attractions are regions or areas becoming tourism destinations which are inside them, there are beauty and uniqueness which can attract tourists to visit to the tourism area. To give high satisfaction to the tourists, thus tourism attraction must be designed and built professionally based on its potency of tourism attraction [13]

\section{The Number of Hotels}

Based on Regional Regulation in Yogyakarta city No.2 Year of 2006 about hotel tax, the meaning of hotel is a special building provided for people to stay, take a rest, get service and or other facilities with giving payment including another building which is united, managed and owned by the same party except shops and offices. According to big dictionary of Bahasa Indonesia that a hotel is a building with many rooms for rent as a place for staying and eating for people who are having travel [14]. Hotel is a kind of accomodation which uses partly or all building to provide lodgement service, eating and drinking that are managed commercially as well as it meets certain condition set by government [15].

\section{E. The Number of Restaurants}

According to $[16,17]$ definition of restaurant is a place or bulding which is organized commercially to have good service to all guests either eating or drinking. Generally, restaurant is a place visited by people in order to find various food and drinking. As well, the restaurant is often served its own uniqueness to attreact customers' attentions through their cuisine menu provided, entertainment as well as performance of restaurant building itself [18].

\section{F. The Number of Tourists}

World Tourism Organization (WTO) gives defination that the meaning of visitor is each person who visits a country which is not their own country with any reasons except having a job paid by country visited $[19,20]$. There are two categories of visitor, namely:

- Tourist is a visitor who stays temporary at least 24 hours in a country he/she visits and the objectives of the travel can be classified as follows:

a. Leisure, for recreational, day off, health, education, religious and exercise.

b. Business, family, conference and others.

- Exursionist is temporary visitor who stays in a country he/she visits less than 24 hours. 
Theoritically in $[21,22,23]$ the longer a tourist stays in an area of tourism destination, the much money he/she spends in that area of the tourism destination, at least his/her needs for eating, drinking and lodgement during staying in that area. Various kinds of tourist needs during his/her tour make them become consumptive for the products which are produced in the area of tourism destination. By consumption activities either from international or domestic tourists, thus, it is going to enlarge tourism sector of an area [24,25]. Therefore, the higher the flow of tourist visits in Special Region of Yogyakarta, the more increase the income of tourism sector.

\section{METHOD}

\section{A. Type and Data Resource}

Data used were secondary data in the form of quarterly data with the time span of 14 years, from 2005 to 2018. The secondary data that were collected involved data regional income of tourism sector, the number of tourists, hotel occupancy rate, total of restaurant tax, and total of entertainment tax. Those data were obtained from publication of tourism office of Yogyakarta city.

\section{B. Data Analysis Method}

Analysis method used in this research was multiple linear regression analysis in order to know the connection and effect of independent variables towards dependent variable. Regression analysis was a method used to analyze connection among variables. Those connections could be expressed in form of equation which connect dependent variable $\mathrm{Y}$ with one or more independent variables. The model of regional income of tourism sector that was used in this research was:

$\mathrm{Y}=\mathrm{f}\left(\mathrm{X}_{1}, \mathrm{X}_{2}, \mathrm{X}_{3}, \mathrm{X}_{4}\right)$

Then function of the regression was transform into multiple logarithm form by using natural logarithm (Ln) as follows [26]

$L Y=\beta_{0}+\beta_{1} L_{1}+\beta_{2} X_{2}+\beta_{3} L_{3}+\beta_{4} L_{4}+e$

In which:

$\mathrm{Y} \quad=$ regional revenue of tourism sector

$\mathrm{LX}_{1}=$ the number of tourists

$\mathrm{X}_{2}=$ hotel occupancy rate

$\mathrm{LX}_{3}=$ total of restaurant tax

$\mathrm{LX}_{4}=$ total of entertainment tax

$\beta_{0}=$ constant

e $\quad=$ error term

$\beta_{1}, \beta_{2}, \beta_{3}, \beta_{4} . \beta_{5}, \beta_{6}=$ elasticity parameter

\section{RESULT AND DISCUSSION}

\section{A. Analysis of Multiple Linear Regression}

Test results of multiple linear regression influence the number of tourists, hotel occupancy rate, restaurant tax, entertainment tax towards regional income of tourism sector in year of 2007.1-2018.4. the results of data processing by multiple linear regression analysis can be shown as follows:

TABLE 1: THE RESULTS OF MULTIPLE LINEAR REGRESSION

\begin{tabular}{|l|c|c|c|}
\hline \multicolumn{1}{|c|}{ Variable } & Coefficient & T-statistic & Prob. \\
\hline $\mathrm{C}$ & -1.998330 & -7.607295 & 0.0000 \\
\hline The number of tourists $\left(\mathrm{LX}_{1}\right)$ & 0.006671 & 0.978718 & 0.0332 \\
\hline Hotel occupancy rate $\left(\mathrm{X}_{2}\right)$ & 2.603632 & -9.610437 & 0.0000 \\
\hline Restaurant tax $\left(\mathrm{LX}_{3}\right)$ & 1.056854 & 47.01829 & 0.0000 \\
\hline Entertainment tax $\left(\mathrm{LX}_{4}\right)$ & 0.060255 & 5.073853 & 0.0000 \\
\hline $\begin{array}{l}\mathrm{F} \text { statistic }=22580.38(\mathrm{p}=0.000000) \\
\mathrm{R}^{2}=0.879524 \\
\text { Adjusted } \mathrm{R}^{2}=0.870480 \\
\mathrm{DW}-\mathrm{stat}=0.282987 \\
\mathrm{~N}=48\end{array}$ & & \\
\hline Source & & \\
\hline
\end{tabular}

Source : secondary data processed, 2020

Mathematically the results of multiple linear regression in equation as follows:

$$
\begin{gathered}
\mathrm{LY}=-1.998330+0.006671 \mathrm{LX}_{1}+2.603632 \mathrm{X}_{2}+1.056854 \\
\mathrm{LX}_{3}+0.060255 \mathrm{LX}_{4}
\end{gathered}
$$

On equation above, it is shown that the effect of the number of tourists, hotel occupancy rate, restaurant tax, entertainment tax towards regional revenue of tourism sector. As for the meanings of coefficient are:

- $\beta_{0}=-1.998330$

It means that if the number of tourists $\left(\mathrm{LX}_{1}\right)$, hotel occupancy rate $\left(\mathrm{X}_{2}\right)$, restaurant tax $\left(\mathrm{LX}_{3}\right)$, entertainment tax $\left(\mathrm{LX}_{4}\right)$ equal to zero (no changes), regional revenue of tourism sector $(\mathrm{Y})$ will decrease as much as -1.998330 .

- $\beta_{1}=0.006671$

It means that if the number of tourists $\left(\mathrm{LX}_{1}\right)$ is as much as 1 percent, regional revenue of tourism sector (Y) will increase as much as 0.006671 percent with assumption that other variables are constant (cateris paribus).

- $\beta_{2}=2.603632$

It means that if increasing of hotel occupancy rate $\left(\mathrm{X}_{2}\right)$ is as much as 1 percent, regional revenue of tourism sector $(\mathrm{Y})$ will increase as much as 2.603632 percent with the assumption that other variables are constant (cateris paribus).

- $\beta_{3}=1.056854$

It means that if increasing of restaurant tax $\left(\mathrm{LX}_{3}\right)$ is as much as 1 percent, regional revenue of tourism sector $(\mathrm{Y})$ will be up as much as 1.056854 percent with the assumption that other variables are constant (cateris paribus).

- $\beta_{4}=0.060255$

It means that if entertainment tax is up $\left(\mathrm{LX}_{4}\right)$ as much as 1 percent, regional revenue of tourism sector (Y) will increase as much as 0.060255 percent with assumption that other variables are constant (cateris paribus). 


\section{B. F test}

F-test is calculated on regression equation above as much as 22580.38 with probability $(\mathrm{p}<0.005)$, thus independent variables are together taken effect towards its dependent variable. The number of tourists, hotel occupancy rate, restaurant tax, entertainment tax are together taken effect towards regional revenue of tourism sector.

\section{T test}

t-test is used to prove the effect of independent variables towards dependent variable individually with the assumption that another variable is stable or constant. The value of coefficient regression of the number of tourists $\left(\mathrm{LX}_{1}\right)$ is as much as 0.006671 . Variable of the number of tourists has tstatistic value as much as 0.978718 and probability value is as much as 0.0332 . Based on positive regression coeffisien value and $\mathrm{p}<0.05$ show that the number of tourists is taken positive effect towards regional revenue of tourism sector. The higher the number of tourists, the higher the regional revenue of tourism sector, vice versa the lower the number of tourists, the lower the regional revenue of tourism sector. Regression coefficient value of hotel occupancy rate $\left(\mathrm{X}_{2}\right)$ is as much as 2.603632. Variable of hotel occupancy rate has t-statistic value as much as -9.610437 and value of probability is as much as 0.0000 . Based on value of positive regression coefficient and $p$ $<0.05$ show that hotel occupancy rate has positive effect towards regional acceptance of tourism sector. The higher the hotel occupancy rate, the higher the regional revenue of tourism sector, vice versa the lower the hotel occupancy rate, the lower the regional revenue of tourism sector. Regression coefficient value of restaurant tax $\left(\mathrm{LX}_{3}\right)$ is as much as 1.056854. Variable of restaurant tax has value of t-statistic as much as 47.01829 and probability value is as much as 0.0000 . Based on value of positive regression coefficient and $p<0.05$ show that restaurant tax gives positive effect towards regional acceptance of tourism sector. The higher the restaurant tax, the higher the regional revenue of tourism sector, vice versa the lower the restairant tax, the lower the regional income of tourism sector. Regression coefficient value of entertainment $\operatorname{tax}\left(\mathrm{LX}_{4}\right)$ is as much as 0.060255 . Variable of entertainment tax has value of t-statistic as much as 5.073853 and probability value is as much as 0.0000 . Based on value of positive regression coefficient and $\mathrm{p}<0.05$ show that entertainment tax has positive effect towards area of tourism sector. The higher the entertainment tax, the higher the regional revenue of tourism sector area. Vice versa the lower the entertainment tax, the lower the regional revenue of tourism sector.

\section{Test of $R^{2}$}

Coefficient of determination $\left(\mathrm{R}^{2}\right)$ basically measures how far the model ability in describing various dependent variables is. Values of determination coefficient are zero and one. Small $\mathrm{R}^{2}$ value means that ability of independent variables in describing various dependent variables is very limited. The value approaching 1 means that independent variables give almost all information needed to predict various dependent variables. From the regression results of the number of tourist, hotel occupancy rate, restaurant tax, entertainment tax towards the regional income of tourism sector in Yogyakarta city in 2007.1-2018.4 are obtained that $\mathrm{R}^{2}$ value is as much as 0.879 .
The result of regression with method of OLS is gained $\mathrm{R}^{2}$ (Coefficient of Determination) as much as 0.879, it means that dependent variable in the model, that is regional revenue of tourism sector (LY) could be explained by various independent variables, namely the number of tourists $\left(\mathrm{LX}_{1}\right)$, hotel occupancy rate $\left(\mathrm{X}_{2}\right)$, restaurant tax $\left(\mathrm{LX}_{3}\right)$ and entertainment tax $\left(\mathrm{LX}_{4}\right)$ as much as $87.9 \%$, whereas, the rest is as much as $12.1 \%$ explained by other factors outside the model.

\section{E. Test of Classical Consumption}

\section{- Normality Test}

One of assumptions in linear regression model is that distribution of interference probability $\mu$ has median which is expected the same as zero, uncorrelated, and having constant varians. Normality test is to test whether in the regression model of interference variable or residual has normal distribution or not [27]. To test whether data are distributed normally or not, it is conducted test of Normality Histogram Statistic.

a. If value of Jarque-Bera or JB test (JB Statistic) is < value of $\chi 2$, thus the data are distributed normally.

b. If value of Jarque-Bera or JB test (JB Statistic) is > value of $\chi 2$, thus the data are not distributed normally.

Result of calculation if value of JB statistic is 20.81763 with $\mathrm{df}=44$, thus $\chi 2$-table will be 60.4809 . It is obtained that value of JB statistic is $20.81763<\chi 2$-table 60.4809 , thus the result means that the variables are distributed normally.

\section{- Linearity Test}

Linearity test is to know whether two variables have significantly linear relation or not. This test is usually used as a prerequisite in analysis of correlation or linear regression. With testing criteria:

a. If probability value of F-Statistic is > alpha $0.05(5 \%)$, thus it can be said that the model complies linearity assumption.

b. If probability value of F-Statistic is < alpha $0.05(\%)$, thus it can be said that the model does not comply linearity assumption.

Calculation result is obtained that probability value of Fstatistic is 17.59196 with alpha value $(\alpha)$. It is gained value of probability $0.0001>\alpha 0.05$, thus, it can be concluded that the model has conformed the assumption of linearity and optimism that there is linearity relation.

- Heteroscedasticity Test

Heteroscedasticity test is to test whether in regression model, there is variance unequality from one observation residual to other observations. In order to know there is or not heteroscedasticity, it is carried out by Harvey test. Calculation result of heteroscedasticity using Harvey test shows that probability value of F-statistic is bigger than alpha (0.05), that is 0.4606 , which means that variables of $\mathrm{LX}_{1}, \mathrm{X}_{2}, \mathrm{LX}_{3}$ and $\mathrm{LX}_{4}$ is bigger than (0.05) therefore, it 
can be concluded that $\mathrm{H}_{1}$ is rejected and $\mathrm{H}_{0}$ is accepted, there is no problem of heteroscedascity on those data.

\section{- Autocorrelation Test}

Autocorrelation test is a correlation between residual in an observation with other observations on regression model. In this research, this test of autocorrelation used is test of Breusch-Godfrey Serial Correlation LM Test. Probability value is $<0.05$, thus there is indication of autocorrelation. Whereas, probability value is $>0.05$, thus there is no indication of autocorrelation. From result of autocorrelation test with method of Breusch-Godfrey, in which probability value of Chi-Square is as much as $0.6000>0.05$, thus it can be concluded that there is no indication of autocorrelation in the research model and it is feasible to be used.

- Multicollinearity Test

Multicollinearity test is to test whether the regression model is found that there is high correlation or infallible among independent variables. Two indicators that become determinant in evaluating test of multicollinearity in regression model are:

High R squared value, however, many independent variables are not significant. By counting correlation coefficient among independent variables $(\mathrm{X})$, if value of coefficient is low, there is no multicollinearity and vice versa. From the result test of multicollinearity, it is obtained that value of VIF LX $\mathrm{L}_{1}$ is as much as 4.77970, $\mathrm{X}_{2}$ as much as $2.39338, \mathrm{LX}_{3}$ as much as 3.83751 and $\mathrm{LX}_{4}$ as much as 5.76655 , thus it can be concluded that value of VIF $<10$ means there is no multicollinearity.

\section{F. Discussion}

This research uses regression test among the number of tourist, hotel occupancy rate, restaurant tax, and entertainment tax as independent variables as well as regional revenue of tourism sector as independent variable. Based on method of multiple linear regression analysis that there are influences among the number of tourists, hotel occupancy rate, hotel tax, restaurant tax, entertainment tax and retribution of tourism attraction towards regional revenue of tourism sector, in which analysis of determination coefficient show that $87.95 \%$ of regional revenue of tourism sector is influenced by the number of tourists, hotel occupancy rate, restaurant tax, and entertainment tax. Based on the research result on hypothesis testing, it shows that all variables are significantly influenced towards regional revenue in Yogyakarta city. It is shown with significant value of variables of the number of tourists, hotel occupancy rate, entertainment tax and restaurant tax, which is less than $\alpha=5 \%$.

\section{CONCLUSION}

By result of analysis and discussion about optimization analysis of regional revenue of tourism sector in Yogyakarta city and factors that influence, it can be concluded as follows: a. Regression coefficient value of the number of tourists $\left(\mathrm{LX}_{1}\right)$ is as much as 0.006671 . Variable of the number of tourists has value of t-statistic as much as 0.978718 and value of probability is as much as 0.0332 . Based on value of positive regression coefficient and $p<0.05$ show that the number of tourists have positive effect towards regional revenue of tourism sector.

b. Regression coefficient value of hotel occupancy rate $\left(\mathrm{X}_{2}\right)$ is as much as 2.603632. Variable of hotel occupancy rate has t-statistic value as much as -9.610437 and value of probability is as much as 0.0000 . Based on value of positive regression coefficient and $p<0.05$ show that hotel occupancy rate takes positive influence towards regional revenue of tourism sector.

c. Regression coefficient value of restaurant tax $\left(\mathrm{LX}_{3}\right)$ is as much as 1.056854. Variable of restaurant tax has t-statistic value as much as 47.01829 and value of probability is as much as 0.0000 . Based on value of positive regression coefficient and $\mathrm{p}<0.05$ show that restaurant tax gives positive effect towards regional revenue of tourism sector.

d. Regression coefficient value of entertainment $\left(\mathrm{LX}_{4}\right)$ is as much as 0.060255 . Variable of entertainment tax has value of t-statistic as much as 5.073853 and value of probability is as much as 0.0000 . based on value of positive regression coefficient and $\mathrm{p}<0.05$ show that entertainment tax has positive effect towards regional revenue of tourism sector.

Based on the result of research that has been done, therefore, the suggestions and feedback to government of Yogyakarta city are as follows:

a. It is suggested to be more organize all tourism attractions in Yogyakarta city, so that it becomes the sources of Own Source Revenue of tourism sector.

b. Government of Yogyakarta city should further improve facilities and infrastructure, because there are the main supporting factor to ease visitors to visit the tourism attractions.

\section{ACKNOWLEDGMENT}

Thanks for comments and suggestions from reviewers and audiences of The 3rd International Conference on Banking, Accounting, Management, and Economics (ICOBAME) 2020.

\section{REFERENCES}

[1] J. Kennedy, J. Ashmore, E. Babister, I. Kelman, The Meaning of 'Build Back Better': Evidence From Post-Tsunami Aceh and Sri Lanka, Journal of Contingencies \& Crisis Management. 16 (2008) 24-36.

[2] S. Mannakkara, S. Wilkinson, Reconceptualising "Building Back Better" to Improve Post-Disaster Recovery, International Journal of Managing Projects in Business. 7 (2014) 327-341.

[3] Gavrilovic Zvjezdana, Mirjana Maksimovic. 2018. Green Innovations in the Tourism Sector. Vol 23 (2018), No. 1, PP. 036-042.

[4] Salah, Wahab. (2003). Manajemen Kepariwisataan. Jakarta: PT. Pramadya Paramita

[5] L. Gibbs, L. Harms, S. Howell-Meurs, K. Block, D. Lusher, J Richardson, C. MacDougall, E. Waters, Community wellbeing: applications for a disaster context, Australian Journal of Emergency Management. 30 (2015) 20-24. 
[6] Dinas Kebudayaan dan Pariwisata Kota Yogyakarta (2019). Data Pendapatan Sektor Pariwisata

[7] S. Mannakkara, S. Wilkinson, Supporting Post-Disaster Social Recovery to Build Back Better, International Journal of Disaster Resilience in the Built Environment. 6 (2015) 126-139.

[8] S. Mannakkara, S. Wilkinson, Build Back Better Principles for Economic Recovery: The Victorian Bushfires Case Study, Journal of Business Continuity and Emergency Planning. 6 (2012) 164-173.

[9] Mursid. (2003). Manajemen Pemasaran (Edisi 1). Jakarta: Bumi Aksara Jakarta Bekerja Sama Dengan Pusat Antar Universitas Studi Ekonomi UI.

[10] S.E. Chang, A.Z. Rose, Towards a Theory of Economic Recovery from Disasters, International Journal of Mass Emergencies and Disasters.32 (2012) 171-181

[11] Elbaz, A.M, Mohamed Yacine Haddoud, Yasser Moustafa Shehawy. (2018). Nopotism, Employees' Com Petencies and Firm Performance in the Tourism Sector: A dual Mmultivariate and Qualitative comparative Analysis Approach

[12] Adhikari Atanu, Saurabh Bhattacharya. (2015). Appraisal of Literature on Customer Experience in Tourism Sector: Review and Framework

[13] Gaziulusoy, H.Z., \& Brezet, H. Design For System Innovations and Transition: A Conceptual Framework Integrating Insights From Sustainability and Transsitions. Journal Of Cleaner Production 108 (2015) 558-568

[14] Widjaya, Marra \& Artyasa, U. (2005). Housekeeping Operation (Tata Graha Perhotelan). Bandung: Humaniora

[15] Al Baatafi, W. 2006. Housekeeping Department Floor \& Public Area. Bandung: Alfabeta

[16] Marsum, A.. (2005). Restoran dan Segala Permasalahannya (Edisi IV). Yogyakarta

[17] S. Mannakkara, S. Wilkinson, Selecting an Institutional Mechanism for Building Back Better: Lessons from Victorian Bushfires Recovery, International Journal of Disaster Risk Reduction. 19 (2016) 273-279.

[18] M. Antara \& Sumarniasih, M. S, "Role of Tourism in Economy of Bali and Indonesia. Journal of Tourism and Hospitality Management", 5 (2), (2017) 34-44.

[19] Antari, N. L. (2013). Peran Industri Pariwisata Terhadap Penerimaan Pendapatan Asli Daerah Kabupaten Gianyar. Jurnal Perhotelan Dan Pariwisata, 3 No 1, 36

[20] G. J. Ashworth, \& Goodall, B, “Marketing Tourism Places", Routledge, (2017).

[21] Qadarrochman, N. (2010). Analisis Penerimaan Daerah Dari Sektor Pariwisata Di Kota Semarang Dan Faktor-Faktor Yang Mempengaruhinya, 119
[22] V. Basera,"Tourism Marketing Strategies and Domestic Tourism Demand in Kariba Resort (Zimbabwe)". Journal of Tourism \& Hospitality, 7(2), (2018). 1-7.

[23] J. Fridgen, "Dimensions of Tourism. Educational Institute of the American Hotel Motel Assoc.", https://www.abebooks.com/9780866121040/Dimensions-TourismJoseph-Fridgen-0866121048/plp, (1991).

[24] A. Holik, "Relationship of Economic Growth with Tourism Sector. Journal of Economics and Policy", 9(1), 16-33, (2016).

[25] Gujarati, Damodar. 2003. Basic Econometrics. Mc Graw Hill.New York

[26] Ghozali, Imam. (2016). Aplikasi Analisis Multivariete Dengan Program IBM SPSS 23 (Edisi 8). Cetakan ke VIII. Semarang: Badan Penerbit Universitas Diponegoro. 